\title{
Analisa Kadar Kromium VI [Cr (VI)] Air di Kecamatan Tanggulangin, Sidoarjo
}

\author{
Ary Andini \\ Prodi DIV Analis Kesehatan, Fakultas Kesehatan, \\ Universitas Nahdlatul Ulama Surabaya \\ Email: aryandini@unusa.ac.id
}

\begin{abstract}
Tanggulangin is one of the sub-districts in Sidoarjo district affected by Lapindo mudflow caused by oil drilling system error located in the area of Siring, Porong. Therefore it had impacted the water quality in around Lapindo mudflow area. The aim of this research was to analysis the levels of water $\mathrm{Cr}$ (VI) Tanggulangin district. Water sample was analyzed by spectrophotometer with wavelength of $540 \mathrm{~nm}$ and done using two (2) steps, which were(1) establishment of standard curve and (2) determination of $\mathrm{Cr}$ (VI) in water. Ten (10) water samples were taken from various villages in the subdistrict Tanggulangin. Based on the results on level of water chromium VI [Cr (VI)] analyze showed 4 of 10 samples had levels of water $\mathrm{Cr}$ (VI)higher than standard 0,05 $\mathrm{mg} / \mathrm{L}$ (PP No.82 tahun 2001), those sample were 1, 3,4 and 10.
\end{abstract}

Keywords: Water, Chromium, Sidoarjo

\section{PENDAHULUAN}

Air menjadi salah satu sumber utama dalam menjaga keberlangsungan hidup seluruh makhluk hidup, tanpa air tidak akan ada kehidupan di dunia ini. Air yang layak konsumsi memiliki ciri tidak berwarna, tidak berbau, tidak berasa dan tidak ada endapan padat terlarut. Salah satu logam berat yang berbahaya bagi kesehatan jika terkandung dalam air adalah kromium (VI) [Cr(VI)] bersifat karsinogenik bagi tubuh (Jacobs et al., 2004).

Kromium (VI) [Cr(VI)] dapat masuk ke badan perairan dengan dua cara, yaitu cara alamiah dan nonalamiah. Masuknya $\mathrm{Cr}$ secara alamiah seperti erosi atau pengikisan pada batuan mineral dan debu-debu atau partikel $\mathrm{Cr}$ yang ada di udara akan dibawah turun oleh air hujan (Departemen Kesehatan, 2009; Bugis dkk, 2013). Masuknya Cr secara non alamiah lebih berkaitan dengan aktifitas manusia seperti buangan limbah industri dan rumah tangga ke badan air (Departemen Kesehatan, 2009; Bugis dkk, 2013). Logam berat bersifat toksik bagi makhluk hidup baik melalui udara, air dan makanan yang terkontaminasi oleh logam berat, logam tersebut dapat terdistribusi ke bagian tubuh manusia dan sebagian akan terakumulasi (Bugis dkk, 2013). Logam Cr yang masuk ke lingkungan dapat berasal dari berbagai sumber, tetapi sumber umum yang diduga paling banyak berpengaruh yaitu dari aktivitas industri, pertambangan, kegiatan rumah tangga dan zat sisa pembakaran serta mobilitas bahan bakar (Bugis dkk, 2013). Akibat dampak buruk yang diakibatkan oleh $\mathrm{Cr}$ (VI) maka pemerintah mengeluarkan PP No. 82 tahun 2001 mengenai kadar maksimum $\mathrm{Cr}$ (VI) untuk keperluan air baku air minum dan kegiatan perikanan sebesar $0,05 \mathrm{mg} / \mathrm{L}$ (Bugis dkk, 2013). 
Kecamatan Tanggulangin merupakan salah satu kecamatan yang terkena dampak akibat semburan Lumpur Lapindo akibat kesalahan sistem pengeboran minyak yang terletak di daerah Siring, Porong (Solihin, 2010). Hal ini berdampak cukup buruk bagi kualitas air di kawasan sekitar Lumpur Lapindo tersebut. Oleh karena itu, dalam penelitian ini dilakukan analisa kadar $\mathrm{Cr}(\mathrm{VI})$ air sumur di kecamatan Tanggulangin untuk mengetahui tingkat pencemaran air akibat $\mathrm{Cr}(\mathrm{VI})$ yang terlarut dalam air.

\section{METODE}

Penelitian analisa kadar $\mathrm{Cr}(\mathrm{VI})$ air di kecamatan Tanggungin, Sidoarjo menggunakan 10 sampel air yang diambil secara langsung di beberapa desa di kecamatan Tanggulangin, Sidoarjo, diantaranya: desa Putat, desa Kedung Banteng, desa Banjar Asri, desa Banjar Panji, desa Kalidawir, dan desa Pelataran, selanjutnya diuji kadar $\mathrm{Cr}(\mathrm{VI})$ air di Laboratorium Terpadu, Universitas Nahdlatul Ulama Surabaya. Penelitian ini dilakukan dengan metode spektrofotometri dalam dua tahapan yaitu pembuatan kurva standard dan penentuan kadar $\mathrm{Cr}(\mathrm{VI})$ dalam sampel air.

Tahap persiapan sampel dilakukan menyiapkan reagen difenil karbazid dan pembuatan larutan Cr (VI) standard. Reagen difenil karbazid didapatkan dengan melarutkan 0,125 mg Kristal difenilkarbazid dalam $25 \mathrm{ml}$ aseton. Pembuatan larutan Cr (VI) 100 ppm didapatkan dengan melarutkan $10 \mathrm{~g}$ Kristal $\mathrm{K} 2 \mathrm{Cr} 2 \mathrm{O} 7$ yang dilarutkan dengan aquades dalam labu ukur $100 \mathrm{ml}$. Selanjutnya pembuatan kurva standar $\mathrm{Cr}(\mathrm{VI})$ dilakukan dengan memasukkan larutan $\mathrm{K} 2 \mathrm{Cr} 2 \mathrm{O} 7$ dengan volume $0 ; 0,2 ; 0,4 ; 0,6,0,8$ dan $1 \mathrm{ml}$ pada masing-masing beaker glass, kemudian menambahkan $\mathrm{H} 2 \mathrm{SO} 40,18 \mathrm{M}$ berturut-turut dengan volume $10 \mathrm{ml} ; 9,8 \mathrm{ml} ; 9,6 \mathrm{ml} ; 9,4 ; 9,2$ $\mathrm{ml}$ dan $1 \mathrm{ml}$, selanjutnya menambahkan $0,5 \mathrm{ml}$ difenilkarbazid dan diamkan selama 5 menit agar terjadi perubahan warna secara optimum, selanjutnya pengukuran larutan standar diukur absorbansinya dengan spektrofotometer UVVis Thermo Scientific Genesys 840-208100 pada panjang gelombang $540 \mathrm{~nm}$. Tahap penentuan $\mathrm{Cr}(\mathrm{VI})$ pada sampel air dilakukan dengan menyaring sampel air terlebih dahulu dengan kertas saring, kemudian mengambil 10 ml sampel dan dilarutkan dengan 12 tetes $\mathrm{H} 2 \mathrm{SO} 43 \mathrm{M}$, selanjutnya menambahkan $0,5 \mathrm{ml}$ difenil karbazid, didiamkan selama 5 menit dan sampel air diukur absorbansinya dengan spektrofotometer Uv-Vis Thermo Scientific Genesys 840-208100 pada panjang gelombang $540 \mathrm{~nm}$. Hasil yang diperoleh selanjutnya dianalisis secara deskriptif (BSN, 2006; Bugis dkk, 2013; Dian, 2015; Onchoke and Sasu, 2016).

\section{HASIL}

Dalam melakukan uji kadar $\mathrm{Cr}(\mathrm{VI})$ dalam air dengan metode spektrofotometri dibutuhkan penentuan kurva kalibrasi sebagai standar dalam perhitungan kadar $\mathrm{Cr}$ (VI) air. Adapun hasil pengukuran kadar $\mathrm{Cr}(\mathrm{VI})$ dengan spektrofotometer pada berbagai konsentrasi utuk kurva standard kalibrasi dapat diamati pada tabel 1 dan gambar dari kurva standard Cr VI dapat dilihat pada gambar 1.

Tabel 1. Absoransi Cr(VI) pada berbagai konsentrasi untuk penentuan kurva stadar $\mathrm{Cr}(\mathrm{VI})$

\begin{tabular}{|c|c|}
\hline $\begin{array}{c}\text { Konsentrasi } \\
(\mathbf{p p m})\end{array}$ & Absorbansi \\
\hline 0 & -0.082 \\
\hline 0,2 & 0.356 \\
\hline 0,4 & 0.379 \\
\hline 0,6 & 0.393 \\
\hline 0,8 & 0.669 \\
\hline 1 & 0.868 \\
\hline
\end{tabular}




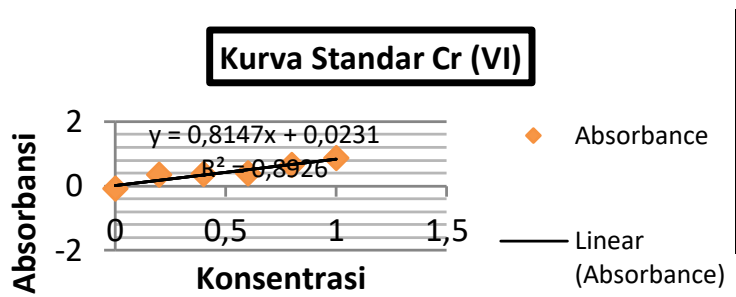

Gambar 4.1 Kurva standard Cr(VI)

Hasil dari pengukuran absorbansi tiap sampel air yang digunakan dapat diamati pada Tabel 2.

Tabel 2. Absorbansi kadar Cr(VI) dalam sampel air

\begin{tabular}{|c|c|}
\hline Lokasi & Absorbansi \\
\hline Titik 1 & 0.132 \\
\hline Titik 2 & 0.057 \\
\hline Titik 3 & 0.251 \\
\hline Titik 4 & 1.86 \\
\hline Titik 5 & 0.058 \\
\hline Titik 6 & 0.047 \\
\hline Titik 7 & 0.047 \\
\hline Titik 8 & 0.033 \\
\hline Titik 9 & 0.058 \\
\hline Titik 10 & 0.086 \\
\hline
\end{tabular}

Hasil pengukuran kadar $\mathrm{Cr}(\mathrm{VI})$ pada air sumur di kawasan kecamatan Tanggulangin dapat diamati pada tabel 3 .

Tabel 3. Hasil Pemeriksaan Kandungan Logam Berat $\mathrm{Cr}(\mathrm{VI})$ dalam air sumur Kecamatan Tanggulangin, Sidoarjo.

\begin{tabular}{|c|c|c|}
\hline $\begin{array}{c}\text { Titik } \\
\text { Pengambilan } \\
\text { Sampel }\end{array}$ & $\begin{array}{c}\text { Kandungan } \\
\text { logam berat } \\
\text { Cr(VI) } \\
(\mathbf{m g} / \mathbf{L})\end{array}$ & Keterangan \\
\hline Titik 1 & 0,133907 & $\begin{array}{c}\text { Tidak memenuhi } \\
\text { standard }\end{array}$ \\
\hline Titik 2 & 0,041769 & Memenuhi standard \\
\hline Titik 3 & 0,280098 & $\begin{array}{c}\text { Tidak memenuhi } \\
\text { standard }\end{array}$ \\
\hline Titik 4 & 2,256757 & $\begin{array}{c}\text { Tidak memenuhi } \\
\text { standard }\end{array}$ \\
\hline Titik 5 & 0,042998 & Memenuhi standard \\
\hline Titik 6 & 0,029484 & Memenuhi standard \\
\hline
\end{tabular}

\begin{tabular}{|c|c|c|}
\hline Titik 7 & 0,029484 & Memenuhi standard \\
\hline Titik 8 & 0,012285 & Memenuhi standard \\
\hline Titik 9 & 0,042998 & Memenuhi standard \\
\hline Titik 10 & 0,077396 & $\begin{array}{c}\text { Tidak memenuhi } \\
\text { standard }\end{array}$ \\
\hline
\end{tabular}

\section{PEMBAHASAN}

Berdasarkan hasil analisa yang dilakukan terhadap parameter $\mathrm{Cr}(\mathrm{VI})$ pada air sumur di kecamatan Tanggulangin menunjukkan bahwa 4 dari 10 sampel air tidak memenuhi standar Peraturan Pemerintah RI Nomor 82 Tahun 2001 tentang Pengelolaan Kualitas Air sungai dan Pengendalian Pencemaran Air, yaitu 0,05 mg/l (Bugis dkk, 2013).

Hasil penelitian pada pengambilan sampel titik 1 sebesar $0,133907 \mathrm{mg} / \mathrm{l}$, pada titik 2 sebesar $0,041769 \mathrm{mg} / \mathrm{l}$, pada titik 3 sebesar 0,280098 $\mathrm{mg} / \mathrm{l}$, pada titik 4 sebesar 2,256757 $\mathrm{mg} / \mathrm{l}$, pada titik 5 sebesar $0,042998 \mathrm{mg} / \mathrm{l}$, pada titik 6 sebesar $0,029484 \mathrm{mg} / \mathrm{l}$, pada titik 7 sebesar $0,029484 \mathrm{mg} / \mathrm{l}$, pada titik 8 sebesar $0,012285 \mathrm{mg} / \mathrm{l}$, pada titik 9 sebesar 0,042998 $\mathrm{mg} / \mathrm{l}$ dan pada titik 10 sebesar $0,077396 \mathrm{mg} / \mathrm{l}$. Sumber air yang digunakan sebagai sampel diambil dari berbagai desa di kawasan kecamatan Tanggulangin yang lokasinya dekat dengan semburan lumpur Lapindo dan seringkali terimbas bau dari semburan lumpur tersebut.

Pada titik 1, 3, 4 dan 10 memiliki kadar $\mathrm{Cr}(\mathrm{VI})$ yang tinggi dan tidak memenuhi standart. Pada titik 1 (desa Pelataran) dan 3 (desa Kedung Banteng) terdapat kolam untuk usaha perikanan dan pemukiman penduduk yang cukup padat sehingga menyebabkan limbah perikanan dan rumah tangga menjadi sumber pencemaran yang mengakibatkan peningkatan kandungan Kromium VI (Cr VI) dalam air. Pada titik 4 (desa Kalidawir) memiliki kadar $\mathrm{Cr}(\mathrm{VI})$ yang paling tinggi 
akibat padatnya pemukiman dan lokasi yang lebih dekat dengan semburan lumpur Lapindo. Pada titik ke-10 (desa Penatar sewu) memiliki kadar $\mathrm{Cr}(\mathrm{VI})$ yang melebihi standard karena kepadatan penduduk yang tinggi menghasilkan limbah rumah tangga yang tinggi juga sehingga $\mathrm{Cr}(\mathrm{VI})$ yang terakumulasi dalam air meningkat (Bugis dkk, 2013; Jacobs et al., 2004).

Air sumur pada umumnya digunakan masyarakat sekitar untuk keperluan sehari-hari dalam berbagai aktivitas baik untuk minum, mencuci, mandi dan lain sebagainya. Apabila air sumur yang dikonsumsi setiap harinya tercemar logam berat $\mathrm{Cr}$ (VI), maka akan mengakibatkan pengendapan $\mathrm{Cr}$ (VI) dalam tanah dan diserap oleh tanaman dan ternak disekitar sumber air, selanjutnya Cr (VI) akan terakumulasi di dalam tanaman dan ternak. Makanan yang berasal tanaman dan ternak yang mengandung endapan $\mathrm{Cr}$ (VI), jika dikonsumsi oleh manusia akan mengendap dalam tubuh (Bugis dkk, 2013; Jacobs et al, 2004). Hal ini bisa menyebabkan penyakit kanker karena sifat $\mathrm{Cr}(\mathrm{VI})$ yang terlarut dalam air bersifat karsinogenik (Jacobs et al, 2004).

\section{KESIMPULAN}

Hasil analisa kadar $\mathrm{Cr}(\mathrm{VI})$ air sumur di kawasan Tanggulangin menunjukkan 4 sampel air yang berasal dari 4 desa memiliki kadar melebihi nilai standard $0,05 \mathrm{mg} / \mathrm{L}$ akibat padatnya pemukiman, aktivitas perikanan dan lokasi yang relatif dekat dengan semburan lumpur Lapindo.

\section{UCAPAN TERIMA KASIH}

Terima kasih kepada Lembaga Penelitian dan Pengabdian Masyarakat (LPPM) Universitas Nahdlatul Ulama Surabaya yang telah mendanai penelitian ini dan Staf Laboratorium Terpadu Universitas Nahdlatul Ulama Surabaya yang membantu terlaksananya penelitian ini.

\section{DAFTAR PUSTAKA}

Badan Standardisasi Nasional (BSN). 2006. Cara uji air minum dalam kemasan. Standar Nasional Indonesia (SNI). SNI 01-3554-2006

Bugis H, Daud A, Birawida A. 2013. Studi Kandungan Logam Berat Kromium VI (Cr VI) Pada Air Dan Sedimen Disungai Pangkajene Kabupaten Pangkep. Fakultas Kesehatan Masyarakat. Universitas Hasanuddin. Makassar.

Departemen Kesehatan. 2009. Rencana Pembangunan Jangka Panjang Bidang Kesehatan 2005-2025. Departemen Kesehatan Republik Indonesia. Jakarta.

Dian A. 2015. Analisis Kandungan Cr (VI) Pada Air Limbah dengan spektrofotometer Uv-Vis, Kimia. Student journal. 1(1) :730 - 736. Universitas Brawijaya Malang

Jacobs J. Testa SM. Avakian CP. 2004. Chromium(VI) Handbook. CRC Press, Page 1-22

Onchoke KK, Sasu SA. 2016.Determination of Hexavalent Chromium (Cr(VI)) Concentrations via Ion Chromatography and UV-Vis Spectrophotometry in Samples Collected from Nacogdoches Wastewater Treatment Plant. Advances in Environmental Chemistry. East Texas (USA).

Solihin T. 2010. Kebijakan Penanganan Lumpur Lapindo Di Kabupaten Sidoarjo Provinsi Jawa Timur. Perencanaan Pembangunan. 16(3).

World Health Organization. 2003. Chromium in Drinking-water Background document for development of WHO Guidelines for Drinking-water Quality. Geneva

Yuliandini A, Putra A. 2013. Pengaruh Formasi Batuan Terhadap Karakteristik Hidrokimia Lima Sumber Mata Air Panas Di Daerah Sapan, Pinang Awan, Kecamatan Alam Pauah Duo, Kabupaten Solok Selatan. Jurnal Fisika Unand. 2(4). 